\title{
Promotion through claiming centrality in L1 and L2 English Research Article Introductions
}

\author{
JALIL ABDI, KARIM SADEGHI* \\ Urmia University (Islamic Republic of Iran)
}

Received: 19/06/2017. Accepted: 30/01/2018.

\begin{abstract}
Marketization in all public spheres, including academic discourse, has led to the increased importance of promotion. One of the promotional tools usually used in Research Articles Introductions (RAIs) is claiming centrality. In this study, we aimed to explore differences between native and non-native writers in the use of strategies for claiming centrality in Applied Linguistics RAIs. To this end, a corpus of 50 English RAIs (25 L1 and 25 L2) was analyzed in terms of the strategies used for claiming centrality. The analysis of the two sets of texts revealed that they are similar in the mean occurrence of centrality claims in general while in terms of the specific strategies used for claiming centrality, there are differences between them. The findings of this study can be used by instructors of writing courses to address promotion better as well as by article authors to report their research findings more convincingly.
\end{abstract}

KEYWORDS: Claiming Centrality, Marketization, Promotion, Research Article Introduction (RAI).

\section{INTRODUCTION}

\subsection{Background}

When public institutions adopt the structures and practices of the market model, marketization is said to have taken place (Fairclough, 1993). Mautner (2010, 2015) has recently introduced and discussed the notion of 'market society', believing that a majority of organizations and sectors in societies have adopted the conventions and practices which are typical features of the market-based relationships. This trend has also influenced the realm of

*Address for correspondence: Karim Sadeghi. Urmia University, Department of English Language and Literature, Urmia, Islamic Republic of Iran; e-mail: k.sadeghi@urmia.ac.ir 
discourse, where "ways of talking that were originally confined to the commercial world are now commonplace in the public sphere generally -in government and public administration, in education, health care, culture, sports, and many other domains" (Mautner, 2015: 1). Academia has not been an exception. Fairclough (1993) argues that academic environment has also been marketized because of the fact that universities are required to operate as businesses, selling their products to consumers. Also, Wernick (1991: vii) reports that academic discourse has been permeated by "promotional culture", which is a typical feature of market-based practices.

In recent years, publication of scientific Research Articles (RAs) has become one of the determinant factors in scholars' professional promotion. On the other hand, the degree of competitiveness in publishing papers in top tier journals continues to grow (Hanauer \& Englander, 2011; Lillis \& Curry, 2010). Therefore, in such a condition, scholars need to employ appropriate structural and rhetorical tools to demonstrate the value of their work and gain acceptance among other members and gatekeepers of the related disciplinary community (Martin \& Perez, 2014). This is where promotionalism comes in. Through the use of discoursal and rhetorical elements which function to enhance the perceived value of one's research (Bhatia, 2005), writers promote their research to others. Bekenkotter and Huckin (1995: 43) also argue that "today's scientists seem to be promoting their work to a degree never seen before." For them, one of the main reasons for the increase of promotion is rooted in the current promotional culture, which is changing discoursal practices and creating hybrid genres.

\subsection{Promotion in the literature}

Promotion can be expressed in various forms as it can be "realized by means of those linguistic choices that seek to change or affect the opinions or behaviors of an audience in terms of positively assessing the research contribution" (Martin \& Perez, 2014: 1). It has been studied as a discourse feature realized through evaluation (e.g. Hunston \& Thomson, 2000), metadiscourse (e.g. Hyland, 2005), and lexicogrammatical features such as selfreference and self-citation (e.g. Afros \& Schryer, 2009; Harwood, 2005a, 2005b; Hyland, $2000,2005)$. Some other strategies have also functioned as promotional elements, such as explicitly highlighting the novel contributions of the study to the discipline or commenting briefly on the findings in the introduction section (Martin \& Perez, 2014).

Most of the studies related to promotion have investigated the introduction sections of RAs (Afros \& Schryer, 2009; Berkenkotter \& Huckin, 1995; Bhatia, 2004; Lindeberg, 2004). This section has been a major focus of attention since it "generally entails a great deal of complexity in terms of rhetorical options, among them the possibility of including promotional elements" (Martin \& Perez, 2014: 2). Analyzing the rhetorical structure of 
introductions has proved to be the most fruitful method in order to gain an in-depth understanding of, among other things, how promotional elements are employed by the authors of RAs. Swales' (1990) seminal work on the rhetorical structure of introduction has been revolutionary in the analysis and teaching of academic writing. He came up with a model, namely the Create a Research Space (CARS) model, which has been the basis of numerous subsequent studies (e.g. Bhatia, 1993; Burgess, 2002; Fredrickson \& Swales, 1994; Loi, 2010; Nwugo, 1991).

Swales' (1990) CARS model is a framework proposed to describe the organizational patterns of writing the Introduction sections in academic research articles. This model assumes that writers, in an attempt to develop an effective introduction to their research articles, follow a general organizational pattern. The model comprises three main actions referred to as 'Moves', each of which consists of a number of 'Steps' as illustrated in Table 1 and briefly explained below.

\begin{tabular}{|l|}
\hline Move 1: Establishing a territory \\
\hline Step 1: Claiming centrality and/or \\
Step 2: Making topic generalization(s) and/or \\
Step 3: Reviewing items of previous research \\
\hline Move 2: Establishing a niche \\
\hline Step 1A: Counter-claiming or \\
Step 1B: Indicating a gap or \\
Step 1C: Question-raising or \\
Step 1D: Continuing a tradition \\
\hline Move 3: Occupying the niche \\
\hline Step 1A: Outlining purposes or \\
Step 1B: Announcing present research \\
Step 2: Announcing principal findings \\
Step 3: Indicating RA structure \\
\hline
\end{tabular}

Table 1. Create-a-Research-Space (CARS) model (Swales, 1990: 141).

As Table 1 shows, Move 1 generally sets the ground for introducing the research topic. Step 1 of the first move is claiming centrality, which is defined by Swales (1990) as appeals through which authors argue that their research is "part of a lively, significant or well established research area" (p. 144). In Step 2, statements are made about the current state of knowledge and the need for further investigations in the area. In Step 3, authors review one or two studies that they consider to be relevant to the establishment (Swales, 1990).

In Move 2, authors try to persuade readers that their research is important and valuable (Swales, 1990). In Step 1A, authors point out the limitations of the general research area; in Step 1B, authors develop a research problem around a gap in the literature; in Step 1C, they 
raise key questions in the area; and in Step 1D, authors generally pose a weaker challenge to the prior research, aiming to expand or clarify a specific research problem (Swales, 1990).

In Move 3, writers discuss the contribution and organizational structure of their paper (Swales, 1990). In Step 1A, they indicate their main purpose(s); in Step 1B, they describe the main features of their research. In Step 2, authors provide a general summary of key findings, and in Step 3, they bring statements about the structure of the remainder of the article (Swales, 1990).

Later in another book, Swales (2004) made some revisions to his model, which are minor and have not changed the basic structure. As can be seen in Table 2, the moves are roughly the same in the revised version of the model, with a minor difference in the wording of the third move. The steps have undergone relatively more changes, with some steps in the original model omitted and some others added. The order of the steps and their wordings have also been revised. However, it seems that the literature on claiming centrality has mostly favored the original model since it has specifically treated claiming centrality as a separate step in introduction sections, though this does not mean that the revised version totally ignores this rhetorical tool.

\begin{tabular}{|l|}
\hline Move 1: Establishing a territory (citation required) via \\
\hline Topic generalization of increasing specificity \\
\hline Move 2: Establishing a niche (citations possible) via \\
\hline Step1A: Indicating a gap or \\
Step1B: Adding to what is known \\
Step 2: (optional) Presenting positive justification \\
\hline Move 3: Presenting the present work (citation possible) via \\
\hline Step 1: (obligatory) Announcing present research descriptively and/or purposively \\
Step 2: (optional) Presenting research questions (RQs) or hypotheses \\
Step 3: (optional) Definitional clarifications \\
Step 4: (optional) Summarizing methods \\
Step 5: (Probable in Some Fields) Announcing principal outcomes \\
Step 6: (PISF) Stating the value of the present research \\
Step 7: (PISF) Outlining the structure of the paper \\
\hline
\end{tabular}

Table 2. Revised version of CARS model (Swales, 2004: $230 \& 232$ ).

Lindeberg (2004) argues that Swales' CARS model is based on the rhetorical claiming of territory and niche. For her, the notion of niche itself is rooted in marketing. Furthermore, Berkenkotter and Huckin (1995) note that the rhetorical structure of this model is essentially promotional. Swales himself appears to highlight the promotional aspect of 'claiming centrality' while other moves and steps are also somehow associated with promotion 
(Lindeberg, 2004), though it should be noted that the CARS model is not meant for the specific investigation of promotion.

In another part of her study, Lindeberg (2004) investigated promotion in other parts of the CARS model as well. She showed that in Move 1, the research topic is promoted through highlighting its importance (claiming centrality); in Move 2, the gap is promoted by presenting the inadequacy of prior research so as to justify the conduction of further research (indicating gaps), and in Move 3, the research is promoted on the basis of the possible contributions it can offer to the discipline (announcing principal findings). She considered claims of centrality as a direct promotional strategy and identified six types of appeals writers in the field of economy make to realize it, that is, appeals to authority, economy, practitioner, research, scope, and topicality. However, in other disciplines including Applied Linguistics claiming centrality had not been elaborated until very recently.

In an in-depth analysis, Wang and Yang (2015) investigated claiming centrality as a promotional strategy in the introduction section of Applied Linguistics RAs. They analyzed 51 RA introductions from three top tier journals in the field, namely, TESOL Quarterly, Modern Language Journal, and Applied Linguistics both qualitatively and quantitatively. Although they used CARS model as the starting point, they did not confine themselves to the first move of the model. Noting that centrality claims can appear in other moves as well, they searched for its realization throughout the introduction section. First, based on the kind of value expressed in the text, they identified four types of appeals, namely, appeals to salience, magnitude, topicality, and problematicity. Then, they identified two types of entities to which the appeals can be ascribed. As these are the categories of analysis for the present study, we shall discuss them in detail below in the methods section.

After completing the qualitative part, Wang and Yang (2015) also conducted a quantitative analysis to investigate the prevalence of each type of appeals and their orientation. They found that claiming centrality through appeal to magnitude had the highest prevalence. With a minor difference, appeal to salience was the second in terms of the frequency of occurrence. The appeal to problematicity was the third most frequent strategy, which was just slightly more prevalent than appeal to topicality, which had the lowest occurrence in the introduction section of Applied Linguistics RAs. As regards the orientation of the claims, their results showed that centrality is claimed making reference to both research and real worlds, though reference to the former was found to be slightly more frequent ( $51.3 \%$ vs $48.7 \%$, respectively).

\subsection{Significance and purpose of the study}

Objective reporting of research findings is the socially recognized purpose of RAs (e.g. Barrass, 2002; Zobel, 2004). On the other hand, it is argued that academic writing carries a 
representation of the writer (Hyland, 2002; Ivanic, 1998), is interactional in nature (Hyland, 2004) and has been permeated with promotion (Mautner, 2010). Bearing these in mind, it seems that gaining the ability to observe all these disciplinary and generic conventions requires much more effort and awareness. This becomes even more difficult when one writes in a language other than his/her mother tongue where interference from their first language can add to the complexity of the issue. Thus, more studies are needed to raise writers' awareness about these aspects of RAs.

From among the aspects of RAs mentioned above, promotion has received less attention, especially when it comes to the specific strategies serving that. Claiming centrality, as one of the promotional strategies, has been investigated by Lindeberg (2004) in a study which dealt with promotion in the three disciplines of Financing, Organization and Management, and Marketing, some of the findings of which were reported above. Another study in this regard was conducted by Wang and Yang (2015), who analyzed claiming centrality in the discipline of Applied Linguistics, which was also reported above. To the best of our knowledge, no study has investigated intercultural differences in the ways through which academic writers claim centrality. Thus, in the present study, we aim to explore the introduction section of RAs written by native English speakers (L1 RAs) and those written by Iranian non-native writers (L2 RAs) in order to highlight their possible differences and/or similarities in promoting their research through the strategies of claiming centrality.

\section{METHODS}

\subsection{Corpus of the study}

As mentioned above, our aim in this research was to study the strategies for claiming centrality in the introduction section of L1 and L2 Applied Linguistics RAs. In so doing, a total of 50 articles (see appendix for the list of articles) were compiled, whose introduction sections formed the corpus to be studied. 25 articles were L1, that is, they were written by native English speakers and 25 articles were L2, that is, they were written by Iranian nonnative writers. Since no computer software has been developed for analyzing this rhetorical feature, we could not include larger number of articles in our corpus, though, a review of the studies conducted in this area as well as areas similar to this shows that analyses of such features in such corpus sizes in a discipline can actually provide us with an overall understanding of their pattern of use (e.g. Afros \& Schryer, 2009; Bruce, 2014; Martin \& Perez, 2014; Yang, Zheng \& Ge, 2015). For example, Afros and Schryer (2009) analyzed only 20 articles to investigate the use of promotional metadiscourse or, in another study, Yang et al. (2015) analyzed a total number of 25 RAs to explore the use of epistemic 
modality. Although we acknowledge that a bigger corpus is more advantageous, following the established trend, we are also justified in our decision that 25 articles from each subcorpus would be enough to obtain dependable results.

The L1 articles were selected from top tier journals in the field, namely, Assessing Writing, Language Teaching Research, Journal of Second Language Writing, System, and International Journal of Bilingualism. The authors' being native was judged by their affiliation and biodata. L2 articles, on the other hand, were taken from two prestigious national journals in the discipline of Applied Linguistics, namely, the Iranian Journal of Language Teaching Research and The Journal of Teaching Language Skills, which mainly publish articles written by Iranian writers. These journals are two of the most highly subscribed journals by Iranian applied linguists, with the former included in Scopus and recently ranked as Iran's top applied linguistics journal. In the selection of the articles, a number of criteria were considered. The first criterion was being empirical in nature; we did not include articles consisting of reviews or reinterpretation of other studies. The second criterion was having the four major sections of a typical RA, namely Introduction, Method, Results, and Discussion. And the third criterion was the publication date of the articles, which was limited to 2010 onwards so as to eliminate any possible effect of time on the ways through which authors claim centrality. The total number of words of the corpus was 29,204 apart from the words appearing in tables, figures, footnotes, headers, and the direct quotations from other sources, which were all excluded from the corpus. A detailed overview of the corpus is given in Table 3 .

\begin{tabular}{|c|c|c|c|}
\hline & No. of RAs & $\begin{array}{c}\text { No. of words } \\
\text { in Introductions }\end{array}$ & $\begin{array}{c}\text { Mean length } \\
\text { of Introductions }\end{array}$ \\
\hline L1 & 25 & 14,662 & 586.4 \\
\hline L2 & 25 & 14,542 & 581.6 \\
\hline Total & 50 & 29,204 & 584 \\
\hline
\end{tabular}

Table 3. The corpus of the study.

\subsection{Data analysis}

The units of analysis for this study were taken from Wang and Yang's (2015). Through identifying the types of values foregrounded in texts, they identified four types of appeals in the introduction section of Applied Linguistics RAs, namely, appeals to salience, magnitude, topicality, and problematicity. They also identified two types of entities to which these value statements were ascribed: entities in the real world and entities in the research world.

1) Appeal to salience: In this kind of appeal, "the importance or significance of a research topic or the importance, usefulness, or advantages of a key construct involved in the 
topic in either the research world or the real world is directly stated" (Wang \& Yang, 2015: 166). For instance, in the example below, the importance of the research topic (learning how to negotiate stance and build a relationship with readers) is underscored with reference to the real world (an essential part of developing into a skillful writer).

Example: Learning how to negotiate stance and build a relationship with readers is an essential part of developing into a skillful writer of various types of text ${ }^{1}$. $(\mathrm{L} 1-12)^{2}$

2) Appeal to magnitude: "The appeal to magnitude relates to the prevalence or popularity of a research topic or a phenomenon by indicating, for example, the multiplicity of studies having been conducted on it or researchers' perpetual interest in it, hence its significance implied and the topic indirectly promoted" (Wang \& Yang, 2015: 166). In the example below, the topic (the relationship between motivation and language learning) is promoted through indicating the relatively large number of studies conducted on it over a long time (subject of inquiry for many years) with reference to entities related to the research world.

Example: The relationship between motivation and language learning has also been a subject of inquiry for many years. (L2-2)

3) Appeal to topicality: This type of appeal "relates to the newness or recency of a research topic or a phenomenon" and argues for their centrality by implying that it can "add new knowledge to this little-traversed/novel area" at hand (Wang \& Yang, 2015: 167).

Example: Most recently, age effects have also been implicated in the L1 attrition, or loss, of phonology, morphosyntax, and lexical semantics. (L1-22)

4) Appeal to problematicity: In this type of appeal, the authors claim centrality for their research topic by foregrounding "the conflicts, problems, difficulties, or challenges a topic or a phenomenon involves" (Wang \& Yang, 2015: 168).

Example: ... has caused the researchers to consider the concept of de-motivation as a controversial issue and one of the most influencing obstacles in learning a foreign language. (L2-21)

Wang and Yang (2015) also identified two types of entities to which these appeals can be related: entities in the research world or in the real world. Each of the appeals can be related to either the entities in the research world, such as the research area or the researchers themselves or entities in the real world, such as particular phenomena or population affected 
by those phenomena. In the examples below, in the first two extracts, centrality is claimed through reference to entities in the real world and in the last two statements, it is done through reference to entities in the research world.

1) Learning main language skills, that is, listening, speaking, reading and writing have become important for students all over the world. (L2-11)

2) Therefore, effective writing instruction and assessment are essential elements for student success as they pass through school and prepare for work or college. (L1-20)

3) In the last decade there has been a welcome rise in the number of research studies examining how language teachers can motivate their learners. (L1-16)

4) Concepts of teaching and testing ILP [interlanguage pragmatics] attracted the attention of many researchers. (L2-7)

The introduction sections of the RAs were read through at least twice to get a general understanding of what the research is about. Then, all of the statements claiming centrality of the research in the two groups of texts were identified, counted, and normalized to make the two sets of data comparable. Although the categories of analysis were clear enough, $20 \%$ of the articles in the corpus were coded by another researcher to ensure the consistency in the coding process. To do this, we invited a colleague familiarized with genre and discourse analysis and, after briefing him with the procedure, we asked him to code one-fifth of the randomly selected texts from the corpus. After that, we calculated the inter-coder reliability, which was found to be 0.94 . In other words, only in $6 \%$ of the items was there a disagreement between the two coders, an agreement level that indicates a high level of consistency in the coding.

The mean occurrence of centrality claims was also calculated for each article introduction in the two sets of texts to gain an understanding of the number of centrality claims in a typical RA introduction. We then enumerated the number of centrality claims with specific appeal types separately and calculated the percentage of each appeal type as well as the entities to which they are ascribed (real world entities or research world entities). Finally, the two sets of data obtained from the two groups of writers were compared and contrasted in different aspects to find out their possible differences and/or similarities in the strategies they employ for claiming centrality.

\section{RESULTS AND DISCUSSION}

\subsection{Types of appeals}

In this study, we set out to find out the use of strategies for claiming centrality in the introduction sections of L1 and L2 English RAs. The analysis of 50 RA introductions, 25 L1 
and $25 \mathrm{~L} 2$, revealed some interesting differences and in some cases similarities between L1 and L2 writers, which are discussed in detail below.

The analysis of the overall occurrence of centrality claims in the introduction sections indicated that all of the articles in both groups have employed such claims to promote their research. In this regard, the L1 and L2 writers have acted similarly. This shows the importance of being able to hook the readers and persuade them to go on with the whole article. In her study, Lindeberg (2004) also reported the presence of centrality claims in all of the articles she analyzed. The number of centrality claims used by the two groups of writers was not remarkably different from one another. As the table below reveals, the mean occurrences of such claims per each introduction section for L1 and L2 writers were 5.76 and 6.28 , respectively.

\begin{tabular}{|c|c|c|c|}
\hline RAIs & Nom. of RAIs & Nom. of CC & $\begin{array}{c}\text { Mean nom. of } \\
\text { CC per RAI }\end{array}$ \\
\hline L1 & 25 & 144 & 5.76 \\
\hline L2 & 25 & 157 & 6.28 \\
\hline
\end{tabular}

Table 4. Mean number of centrality claims per RA introduction section. [RAI= RA Introduction; $\mathrm{CC}=$ Centrality Claim].

Based on the above data, we can say that L1 writers and L2 writers are similar in their frequency of using centrality claims. However, further analysis demonstrated that although the frequencies are nearly the same, there are differences between the two groups in the use of different strategies for the realization of claims of centrality.

As discussed earlier, Wang and Yang (2015) have identified four types of appeals in claiming centrality by authors: appeals to salience, magnitude, topicality and problematicity. Analysis of the two sets of texts in terms of the different types of appeals made in order to claim centrality revealed that there are differences between them.

Table 5 below shows the distribution of different types of appeals which are made to claim centrality. As can be seen, the distribution is not the same for the two sets of texts. Before discussing the differences of the two groups of writers, we first discuss the distribution of centrality claims in each sub-corpus independently.

As for L1 sub-corpus, the overall distribution of the different appeals made for claiming centrality in L1 RAIs in this study is different from their distribution in Applied Linguistics RAIs reported by Wang and Yang (2015). In their study, the appeals for magnitude had the highest prevalence while in ours the appeals for salience were the most frequent. Furthermore, the differences among the prevalence of the four appeals were not as 
harsh in our study. These differences might be related to the inclusion of only L1 articles in our L1 sub-corpus while the articles included in their corpus did not have this criterion.

\begin{tabular}{|c|c|c|c|c|c|c|c|c|}
\hline \multirow[t]{2}{*}{ RAIs } & \multicolumn{2}{|c|}{$\begin{array}{l}\text { Appeal to } \\
\text { salience }\end{array}$} & \multicolumn{2}{|c|}{$\begin{array}{l}\text { Appeal to } \\
\text { magnitude }\end{array}$} & \multicolumn{2}{|c|}{$\begin{array}{l}\text { Appeal to } \\
\text { topicality }\end{array}$} & \multicolumn{2}{|c|}{$\begin{array}{c}\text { Appeal to } \\
\text { problematicity }\end{array}$} \\
\hline & Raw & percentage & Raw & percentage & Raw & percentage & Raw & percentage \\
\hline L1 & 59 & $41 \%$ & 54 & $37 \%$ & 21 & $15 \%$ & 10 & $7 \%$ \\
\hline L2 & 80 & $51 \%$ & 47 & $30 \%$ & 16 & $10 \%$ & 14 & $9 \%$ \\
\hline
\end{tabular}

Table 5. Distribution of the types of appeals made to claim centrality.

As for the L2 sub-corpus, again our results are different from Wang and Yang's (2015) findings. According to these researchers, appeals to magnitude are most frequent in the RAIs of Applied Linguistics while our results showed that Iranian nonnative writers mostly make appeals to salience. This might be related to the difference in writing competence levels and vocabulary repertoire of the writers as it seems that the words needed to convey importance and advantage are more frequently used in everyday English, and for Iranian EFL writers, such words are more readily accessible in writing. Another reason might be related to cultural issues. Anecdotally, Iranians consider importance and advantage of an issue by itself as a more valuable and dependable criterion than its prevalence and popularity among other people. In fact, based on our personal experiences, they mostly rely on their own perception rather than basing their judgment on what others think about a subject, an observation which helps better understand why they often tend to focus on salience when claiming centrality.

As for the differences between the two sub-corpora in our study, the results presented in Table 5 indicate that the highest degree of difference between the two groups of writers turned out to be in appeals for salience where L2 writers have made more than half of their centrality claims using this type of appeal while L1 writers have used this type of appeal for $41 \%$ of their centrality claims. Regarding the nature of appeals for salience, this finding shows that L2 writers overly emphasize the salience of their research topic, which might stem from their cultural background mentioned above or from the fact that appeal to salience is the typical and easy way of claiming centrality and is therefore the most readily accessible type of appeal for a non-native writer when he/she wants to make a centrality claim.

As reported in Table 5, the two groups of writers are also different in making appeal to magnitude in order to claim centrality for their research. L1 writers have opted for this type of appeal more than L2 writers: $37 \%$ versus 30\%, respectively. For L1 writers, multiplicity of works done on a specific research area, extensive interest in the issue at hand and the involvement of a great number of people in that area are more important than L2 writers. The 
reason for this might be the wider access of native English speakers to the studies conducted all over the world because of their language being the lingua franca of research articles.

A difference also exists between Iranian English writers and L1 English writers in making appeals for topicality to foreground the centrality of their research, though not as remarkable as the two types discussed earlier. They have made appeals for topicality, i.e., the newness and recency of their research topic in $10 \%$ and $15 \%$ of their centrality claims, respectively. Explicit statement of the timeliness and also positioning and contextualizing one's research in a lively and ongoing research area can serve as a resourceful strategy of promotion, which seems to be relatively overlooked by Iranian non-native writers of English RAIs.

As regards appeal for problematicity, L1 and L2 writers have made $7 \%$ and $8 \%$ of the centrality claims through this type of appeal, respectively. It appears that the two groups are not that much different in this regard. Claiming centrality through appeals to problematicity is relatively the same for the two groups of writers, which shows that they assign somehow equal importance to the challenges and problems present in the field. The reason for this low employment of appeals to problematicity in both sub-corpora might be that such appeals rest on negative attitudinal values unlike the other three types which are associated with positive attitudinal values (Wang \& Yang, 2015). Therefore, maybe the authors tend to promote their work by highlighting the advantages and positive points of their research rather than calling upon readers' negative judgements, hence the low use of appeals to problematicity.

\subsection{Orientations of appeals}

As discussed in the methods section, these different types of appeals which are made to claim centrality can be ascribed to two types of entities: entities in the real world and entities in the research world (Wang \& Yang, 2015). The two sets of RAIs were compared in this regard too. The overall orientations of the appeals are shown in Table 6 below.

As can be seen, both L1 and L2 writers mainly ascribe the importance of their research to the entities in the real world. However, L1 writers tend to rely relatively more on entities in the real world by relating $72 \%$ of their centrality claims to this type of entities. This finding about the L1 writers' tendency to rely mostly on real world entities is somehow inconsistent with the findings of Wang and Yang's (2015) study. They also reported higher prevalence of orientation to real world entities, but in our data its prevalence was found to be remarkably higher. Again, this might be due to the difference in the articles included in the corpus; in our study, the L1 sub-corpus consisted of articles written by native English speakers while they did not have this criterion for the inclusion of articles in their corpus. 


\begin{tabular}{|c|c|c|c|c|}
\hline \multirow{2}{*}{ RAIs } & \multicolumn{2}{|c|}{ Entities in the real world } & \multicolumn{2}{c|}{ Entities in the research world } \\
\cline { 2 - 5 } & Raw & Percentage & Raw & Percentage \\
\hline L1 & 103 & $72 \%$ & 41 & $28 \%$ \\
\hline L2 & 96 & $61 \%$ & 61 & $39 \%$ \\
\hline
\end{tabular}

Table 6. Orientation of appeals to real/research world entities.

L2 writers also demonstrated a stronger tendency to refer to real world entities but with less harsh difference compared to L1 writers. In other words, the distribution of orientations of appeals made for claiming centrality by L2 writers is relatively more similar to their distribution in Applied Linguistics RAIs reported by Wang and Yang (2015).

Overall, the findings of our study revealed that there are some similarities as well as some differences between Iranian L2 writers of English RAIs and English L1 writers. As the results showed, the overall distribution of claims of centrality is similar in the two groups of texts. Nonetheless, differences exist in the use of different strategies used to make centrality claims. Entities to which such claims are associated with also appeared to be different in the two sets of texts.

\section{CONCLUSIONS}

In this study, we explored the different strategies used for claiming centrality in the introduction section of RAs written by native English speakers and those written by Iranian non-native writers. Using Wang and Yang's (2015) study as the framework, we found that in the overall distribution of centrality claims, there is not that much difference between L1 and L2 writers. However, regarding the different appeals which are made for claiming centrality, the two sets of texts are different in the use of appeals for salience, magnitude and, with less harshness, topicality while in terms of problematicity, the two sets of data are almost the same. In addition, it turned out that the orientations of these appeals are also different in the two groups of texts.

Bearing in mind the growing competitiveness of academic publication (Hanauer \& Englander, 2011; Lillis \& Curry, 2010) and the importance of promotion to gain acceptance and attraction (Mautner, 2010), it is important, specifically for L2 writers, to increase their awareness in this regard and closely attend to this aspect of academic writing. Writers need to be made aware that without using such rhetorical strategies in their writings, it will be difficult to position themselves in the relevant disciplinary community and gain credit for their research. Our findings can be beneficial for instructors of writing courses in EAP/ESP programs in addressing this specific discourse feature more systematically and with greater 
detail. This study can be especially resourceful for Iranian (and other non-native) writers since it provides a clear picture of how centrality claims should be made and where considerable differences exist between L2 and L1 writers in this regard. Appreciating this can lead to a better understanding and a smoother organization of academic writing, enabling writers to produce more convincing, well-organized and 'marketable' pieces of writing.

Since we just focused on Applied Linguistics RAs, we could not generalize our findings to other disciplines. It is suggested that other studies be conducted on the RAs of other disciplines. In this way, findings from different studies can complement each other and provide a more comprehensive understanding of the nature of strategies used for claiming centrality. Also, promotion has many realizations in academic written discourse, one of which is claiming centrality. Other studies can focus on other realizations of this nowpervasive phenomenon, which together can provide fruitful information on how to promote one's work.

\section{NOTES}

1 In the examples which are extracted from the corpus, the entities evaluated are underlined and the linguistic devices expressing values are bold type.

2 This code shows the sub-corpus and the number of the article from which the example has been taken.

\section{REFERENCES}

Afros, E., \& Schryer, C. (2009). Promotional (meta)discourse in research articles in language and literary studies. English for Specific Purposes, 28, 58-68.

Barrass, R. (2002). Scientists must write: A guide to better writing for scientists, engineers and students $\left(2^{\text {nd }} e d.\right)$. New York, NY: Routledge.

Berkenkotter, C., \& Huckin, T. N. (1995). Genre knowledge in disciplinary communication: Cognition/Culture/Power. Hillsdale, NJ: Lawrence Erlbaum Associates, Inc.

Bhatia, V. K. (1993). Analyzing genre: Language use in professional setting. London \& New York: Longman.

Bhatia, V. K. (2004). Worlds of written discourse. London \& New York: Continuum.

Bhatia, V. K. (2005). Generic patterns in promotional discourse. In H. Halmari \& T. Virtanen (Eds.), Persuasion across genres: A linguistic approach (pp. 213-225). Amsterdam: John Benjamins.

Bruce, I. (2014). Expressing criticality in the literature review in research article introductions in applied linguistics and psychology. English for Specific Purposes, 36, 85-96

Fairclough, N. (1993). Critical discourse analysis and the marketization of public discourse: The universities. Discourse \& Society, 4(2), 133-168.

Hanauer, D. I., \& Englander, K. (2011). Quantifying the burden of writing research articles in a second language: Data from Mexican scientists. Written Communication, 28, 403-416. 
Harwood, N. (2005a). 'I hoped to counteract the memory problem, but I made no impact whatsoever': discussing methods in computing science using I. English for Specific Purposes, 24, 243-267.

Harwood, N. (2005b). 'Nowhere has anyone attempted ... In this article I aim to do just that': A corpus-based study of self-promotional I and we in academic writing across four disciplines. Journal of Pragmatics, 37, 1207-1231.

Hunston, S., \& Thomson, G. (Eds.). (2000). Evaluation in text: Authorial stance and the construction of discourse. Oxford: Oxford University Press.

Hyland, K. (2000). Disciplinary discourse. Social interactions in academic writing. Harlow: Pearson Education.

Hyland, K. (2002). Authority and invisibility: Authorial identity in academic writing. Journal of Pragmatics, 34, 1091-1112.

Hyland, K. (2004). Disciplinary discourses: Social interactions in academic writing. Ann Arbor: University of Michigan Press.

Hyland, K. (2005). Metadiscourse: Exploring interaction in writing. London \& New York: Continuum.

Ivanic, R. (1998). Writing and identity: the discoursal construction of identity in academic writing. Amsterdam: John Benjamins.

Lillis, T., \& Curry, M. J. (2010). Academic writing in a global context: The politics and practices of publishing in English. London: Routledge.

Lindeberg, A. C. (2004). Promotion and pliteness: Conflicting scholarly rhetoric in three disciplines. Abo, Finland: Abo Akademi University Press.

Loi, C. K. (2010). Research article introductions in Chinese and English: A comparative genre-based study. Jounal of English for Academic Purposes, 9, 267-279.

Martin, P., \& Perez, I. K. L. (2014). Convincing peers of the value of one's research: A genre analysis of rhetorical promotion in academic texts. English for Specific Purposes, 34, 1-13.

Mautner, G. (2010). Language and the market society: Critical reflections on discourse and dominance. NY: Routledge.

Mautner, G. (2015). Marketization of public discourse. In K. Tracy, C. Ilie, \& S. Todd (Eds.), The International Encyclopedia of Language and Social Interaction ( $1^{\text {st }}$ ed., pp. 968-972). John Wiley \& Sons, Inc.

Nwugo, K. N. (1991). Structure of science popularizations: A genre analysis approach to the schema of popularized medical texts. English for Specific Purposes, 10, 111-123.

Swales, J. M. (1990). Genre analysis: English in academic and research settings. Glasgow: Cambridge University Press.

Swales, J. M. (2004). Research genres: exploration and application. Cambridge: Cambridge University Press.

Wang, W., \& Yang, C. (2015). Claiming centrality as promotion in applied linguistics research article introductions. Journal of English for Academic Purposes, 20, 162-175.

Wernick, A. (1991). Promotional culture: Advertising, ideology, and symbolic expression. London: Sage.

Yang, A., Zheng, S., \& Ge, G. (2015). Epistemic modality in English-medium medical research articles: A systemic functional perspective. English for Specific Purposes, 38, 1-10.

Zobel, J. (2004). Writing for computer science. New York, NY: Springer.

(c) Servicio de Publicaciones. Universidad de Murcia. All rights reserved. IJES, vol. 18 (1), 2018, pp. 53-70 Print ISSN: 1578-7044; Online ISSN: 1989-6131 


\section{APPENDIX}

A. Title and DOI of L1 RAs

\begin{tabular}{|c|c|c|}
\hline $\begin{array}{l}\text { Article } \\
\text { number in the } \\
\text { sub-corpus }\end{array}$ & Article title & DOI \\
\hline 1 & $\begin{array}{l}\text { State-of-the-art automated essay scoring: } \\
\text { Competition, results, and future directions from a } \\
\text { United States demonstration }\end{array}$ & 10.1016/j.asw.2013.04.001 \\
\hline 2 & $\begin{array}{l}\text { Cultural contrasts and commonalities in inspiring } \\
\text { language teaching }\end{array}$ & $10.1177 / 1362168814541716$ \\
\hline 3 & $\begin{array}{l}\text { Refugees in first-year college: Academic writing } \\
\text { challenges and resources }\end{array}$ & 10.1016/j.jslw.2014.01.001 \\
\hline 4 & $\begin{array}{l}\text { Besides ... on the other hand: Using a corpus } \\
\text { approach to explore the influence of teaching } \\
\text { materials on Chinese students' use of linking } \\
\text { adverbials }\end{array}$ & 10.1016/j.jslw.2013.07.002 \\
\hline 5 & $\begin{array}{l}\text { Written corrective feedback for individual L2 } \\
\text { writers }\end{array}$ & 10.1016/j.jslw.2012.09.009 \\
\hline 6 & $\begin{array}{l}\text { Sociocultural influences on the use of a web-based } \\
\text { tool for learning English vocabulary }\end{array}$ & 10.1016/j.system.2013.10.015 \\
\hline 7 & $\begin{array}{l}\text { Multilingual writing in an age of accountability: } \\
\text { From policy to practice in U.S. high school } \\
\text { classrooms }\end{array}$ & 10.1016/j.jslw.2011.05.006 \\
\hline 8 & $\begin{array}{l}\text { "I write it in a way that people can read it": How } \\
\text { teachers and adolescent L2 writers describe content } \\
\text { area writing }\end{array}$ & 10.1016/j.jslw.2011.05.005 \\
\hline 9 & $\begin{array}{l}\text { Newcomers developing English literacy through } \\
\text { historical thinking and digitized primary sources }\end{array}$ & 10.1016/j.jslw.2011.05.004 \\
\hline 10 & $\begin{array}{l}\text { Genre-based tasks in foreign language writing: } \\
\text { Developing writers' genre awareness, linguistic } \\
\text { knowledge, and writing competence }\end{array}$ & 10.1016/j.jslw.2011.03.001 \\
\hline 11 & $\begin{array}{l}\text { Task complexity and linguistic and discourse } \\
\text { features } \\
\text { of narrative writing performance }\end{array}$ & 10.1016/j.jslw.2011.02.001 \\
\hline 12 & $\begin{array}{l}\text { Revisiting multiple profiles of learner compositions: } \\
\text { A comparison of highly rated NS and NNS essays }\end{array}$ & 10.1016/j.jslw.2013.10.001 \\
\hline 13 & $\begin{array}{l}\text { Adolescent multilingual writers' transitions across } \\
\text { in- and out-of-school writing contexts }\end{array}$ & 10.1016/j.jslw.2009.10.001 \\
\hline 14 & $\begin{array}{l}\text { Individual factors and successful learning in a } \\
\text { hybrid course }\end{array}$ & 10.1016/j.system.2012.10.013 \\
\hline 15 & $\begin{array}{l}\text { Teaching in the foreign language classroom: How } \\
\text { being a native or non-native speaker of German } \\
\text { influences culture teaching }\end{array}$ & $10.1177 / 1362168814541751$ \\
\hline 16 & $\begin{array}{l}\text { The effect of instruction on pragmatic routines in } \\
\text { academic discussion }\end{array}$ & $10.1177 / 1362168814541739$ \\
\hline 17 & $\begin{array}{l}\text { The effect of instruction on conventional } \\
\text { expressions in L2 pragmatics }\end{array}$ & 10.1016/j.system.2012.01.004 \\
\hline 18 & $\begin{array}{l}\text { The challenges of planning language objectives in } \\
\text { content-based ESL instruction }\end{array}$ & $10.1177 / 1362168813505381$ \\
\hline 19 & Promoting sociolinguistic competence in the & $10.1177 / 1362168811423340$ \\
\hline
\end{tabular}

(C) Servicio de Publicaciones. Universidad de Murcia. All rights reserved. IJES, vol. 18 (1), 2018, pp. 53-70

Print ISSN: 1578-7044; Online ISSN: 1989-6131 


\begin{tabular}{|c|l|c|}
\hline & classroom zone of proximal development & \\
\hline 20 & $\begin{array}{l}\text { How effective are affective activities? Relative } \\
\text { benefits of two types of structured input activities as } \\
\text { part of a computer-delivered lesson on the Spanish } \\
\text { subjunctive }\end{array}$ & $10.1177 / 1362168812436919$ \\
\hline 21 & $\begin{array}{l}\text { Age of acquisition interactions in bilingual lexical } \\
\text { access: A study of the weaker language of L2 } \\
\text { learners and heritagespeakers }\end{array}$ & $10.1177 / 1367006912443431$ \\
\hline 22 & $\begin{array}{l}\text { Automated Essay Scoring feedback for second } \\
\text { language writers: How does it compare to instructor } \\
\text { feedback? }\end{array}$ & $10.1016 /$ j.asw.2014.03.006 \\
\hline 23 & $\begin{array}{l}\text { Instructional rubrics: Effects of presentation options } \\
\text { on writing quality }\end{array}$ & $10.1016 /$ j.asw.2014.03.003 \\
\hline 24 & $\begin{array}{l}\text { Development and validation of a scale to measure } \\
\text { perceived authenticity in writing }\end{array}$ & $10.1016 /$ j.asw.2014.02.001 \\
\hline 25 & $\begin{array}{l}\text { Learning to do concept-based pragmatics } \\
\text { instruction: Teacher development and L2 } \\
\text { pedagogical content knowledge }\end{array}$ & $10.1177 / 1362168814541719$ \\
\hline
\end{tabular}

\section{B. Title and DOI/link of L2 RAs}

\begin{tabular}{|c|c|c|}
\hline $\begin{array}{l}\text { Article } \\
\text { number in } \\
\text { the sub- } \\
\text { corpus }\end{array}$ & Article title & Link to or DOI of the article \\
\hline 1 & $\begin{array}{l}\text { A conversation analysis of the function of } \\
\text { silence in writing conferences }\end{array}$ & ijltr.urmia.ac.ir/article_20366.html \\
\hline 2 & $\begin{array}{l}\text { On the relationship between EFL teachers' } \\
\text { classroom management approaches and the } \\
\text { dominant teaching style: A mixed method study }\end{array}$ & journal.urmia.ac.ir/article_20367.html \\
\hline 3 & $\begin{array}{l}\text { The Effect of Peer and Teacher Scaffolding on } \\
\text { the Reading Comprehension of EFL Learners in } \\
\text { Asymmetrical and Symmetrical Groups }\end{array}$ & $10.22099 /$ jtls.2014.1860 \\
\hline 4 & $\begin{array}{l}\text { An empirical examination of the association } \\
\text { between multiple intelligences and language } \\
\text { learning self-efficacy among TEFL university } \\
\text { students }\end{array}$ & journal.urmia.ac.ir/article_20400.html \\
\hline 5 & $\begin{array}{l}\text { Iranian university English learners' discursive } \\
\text { demotivation construction }\end{array}$ & ijltr.urmia.ac.ir/article_20412.html \\
\hline 6 & $\begin{array}{l}\text { The role of teachers' classroom discipline in } \\
\text { their teaching effectiveness and students' } \\
\text { language learning motivation and achievement: } \\
\text { A path method }\end{array}$ & journal.urmia.ac.ir/article_20402.html \\
\hline 7 & $\begin{array}{l}\text { English teachers' research engagement: Level } \\
\text { of engagement and motivation }\end{array}$ & ijltr.urmia.ac.ir/article_20403.html \\
\hline 8 & $\begin{array}{l}\text { Instrumental and integrative orientations: } \\
\text { Predictors of willingness to communicate in the } \\
\text { Iranian EFL context }\end{array}$ & ijltr.urmia.ac.ir/article_20415.html \\
\hline 9 & $\begin{array}{l}\text { On the accessibility of phonological, } \\
\text { orthographic, and semantic aspects of second } \\
\text { language vocabulary learning and their } \\
\text { relationship with spatial and linguistic } \\
\text { intelligences }\end{array}$ & ijltr.urmia.ac.ir/article_20405.html \\
\hline
\end{tabular}




\begin{tabular}{|c|c|c|}
\hline 10 & $\begin{array}{l}\text { Attitudes towards English Language Norms in } \\
\text { the Expanding Circle: Development and } \\
\text { Validation of a new Model and Questionnaire }\end{array}$ & $10.22099 /$ jtls.2015.3234 \\
\hline 11 & $\begin{array}{l}\text { Diagnosing the Iranian L2 Writing Ability } \\
\text { Using Self-Assessment and Level Specific } \\
\text { Approaches }\end{array}$ & $10.22099 /$ jtls.2015.3459 \\
\hline 12 & $\begin{array}{l}\text { The Generic Structure of Acknowledgments in } \\
\text { Persian Dissertations }\end{array}$ & $10.22099 /$ jtls.2016.3580 \\
\hline 13 & $\begin{array}{l}\text { De-Motivators, Burnout and Language } \\
\text { Achievement in an Iranian EFL Context }\end{array}$ & $10.22099 /$ jtls.2015.3585 \\
\hline 14 & $\begin{array}{l}\text { Academic Writing Revisited: A Phraseological } \\
\text { Analysis of Applied Linguistics High-Stake } \\
\text { Genres from the Perspective of Lexical Bundles }\end{array}$ & $10.22099 /$ jtls.2016.3615 \\
\hline 15 & $\begin{array}{l}\text { Three Types of Comments on Content: Teacher } \\
\text { vs. Peer Feedback }\end{array}$ & $10.22099 /$ jtls.2016.3656 \\
\hline 16 & $\begin{array}{l}\text { The Impact of Task Complexity along Single } \\
\text { Task Dimension on EFL Iranian Learners' } \\
\text { Written Production: Lexical complexity }\end{array}$ & $10.22099 /$ jtls.2016.3685 \\
\hline 17 & $\begin{array}{l}\text { The Effect of Mixed and Matched Level Dyadic } \\
\text { Interaction on Iranian EFL Learners' } \\
\text { Comprehension and Production of Requests and } \\
\text { Apologies }\end{array}$ & $10.22099 /$ jtls.2016.3728 \\
\hline 18 & $\begin{array}{l}\text { The Use of Hedging in Discussion Sections of } \\
\text { Applied Linguistics Research Articles with } \\
\text { Varied Research Methods }\end{array}$ & $10.22099 /$ jtls.2016.3729 \\
\hline 19 & $\begin{array}{l}\text { Demotivating Factors Affecting Undergraduate } \\
\text { Learners of Non-English Majors Studying } \\
\text { General English: A Case of Iranian EFL } \\
\text { Context }\end{array}$ & $10.22099 /$ jtls.2014.1859 \\
\hline 20 & $\begin{array}{l}\text { The relationship between Iranian EFL learners' } \\
\text { self-regulatory vocabulary strategy use and } \\
\text { their vocabulary size }\end{array}$ & ijltr.urmia.ac.ir/article_20388.html \\
\hline 21 & $\begin{array}{l}\text { Iranian EFL teachers and learners perspective } \\
\text { on potentiality of Top Notch series for } \\
\text { intercultural competence development }\end{array}$ & ijltr.urmia.ac.ir/article_20389.html \\
\hline 22 & $\begin{array}{l}\text { Teachers' and students' amount and purpose of } \\
\text { L1 use: English as foreign language (EFL) } \\
\text { classrooms in Iran }\end{array}$ & journal.urmia.ac.ir/article_20390.html \\
\hline 23 & $\begin{array}{l}\text { On the relationship between justice judgments, } \\
\text { outcomes and identity orientations among } \\
\text { Iranian EFL learners: A structural equation } \\
\text { model }\end{array}$ & ijltr.urmia.ac.ir/article_20392.html \\
\hline 24 & $\begin{array}{l}\text { Pragmatic assessment of request speech act of } \\
\text { Iranian EFL learners by non-nativeEnglish } \\
\text { speaking teachers }\end{array}$ & ijltr.urmia.ac.ir/article_20363.html \\
\hline 25 & $\begin{array}{l}\text { The effect of written corrective feedback on } \\
\text { grammatical accuracy of EFL students: An } \\
\text { improvement over previous unfocused designs }\end{array}$ & journal.urmia.ac.ir/article_20365.html \\
\hline
\end{tabular}

